\title{
A VEGETAÇÃO DO PARQUE ESTADUAL DO ESPINILHO. 2 - ORIGEM DO NOME E CONSIDERAÇÕES FITOGEOGRÁFICAS ${ }^{1}$
}

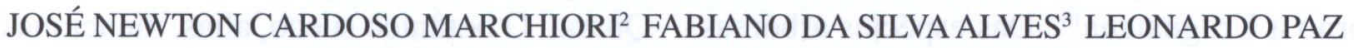 \\ DEBLE $^{4}$ ANABELA SILVEIRA DE OLIVEIRA DEBLE ${ }^{5}$
}

\section{RESUMO}

A origem do nome e as tipologias de vegetação reconhecidas no Parque Estadual do Espinilho (Rio Grande do Sul, Brasil) são presentemente investigadas, com vistas ao esclarecimento de questões fitogeográficas pendentes na literatura.

Palavras-chave: Barra do Quaraí, Fitogeografia, Parque Estadual do Espinilho, Rio Grande do Sul.

\section{ABSTRACT}

[The vegetation of Espinilho State Park (Rio Grande do Sul, Brazil). 2 - Origin of the name and phytogeographical comments].

The origin of the name and the vegetation types recognized in the Espinilho State Park (Rio Grande do Sul State, Brazil) are investigated, with the aim to clarifying phytogeographical questions found in the literature. Keywords: Barra do Quaraí, Espinilho State Park, Phytogeography, Rio Grande do Sul State.

\section{INTRODUÇÃO}

Situado no extremo sudoeste do Rio Grande do Sul, no município de Barra do Quaraí, o Parque Estadual do Espinilho dispõe de bibliografia relativamente escassa, marcada pela repetição de equívocos esclarecidos há bastante tempo. O presente artigo visa a analisar a origem do nome oficial da unidade de conservação, bem como descrever, resumidamente, as diferentes tipologias de vegetação nela existentes, com base em coletas e estudos desenvolvidos ao longo de mais de trinta anos.

1 Recebido em 15-6-2013 e aceito para publicação em 23-11-2013.

2 Engenheiro Florestal, Dr. Bolsista de Produtividade em Pesquisa (CNPq - Brasil). Professor Titular do Departamento de Ciências Florestais, Universidade Federal de Santa Maria.marchiori@pq.cnpq.br

3 Biólogo, Dr. Professor do Curso de Ciências Biológicas, URCAMP (Alegrete, RS).

4 Biólogo, Dr. Professor do Curso de Ciências da Natureza, UNIPAMPA (Dom Pedrito, RS).

5 Bióloga, Dra. Professora do Curso de Tecnólogo em Gestão Ambiental, URCAMP (Dom Pedrito, RS).

\section{COMENTÁRIOS SOBRE O NOME}

Não restam dúvidas sobre a origem do termo "Parque Espinilho", aplicado à unidade de conservação $0^{6}$ criada pelo governo do Estado do Rio Grande do Sul no Município de Barra do Quaraí: cunhado por Balduíno Rambo ${ }^{7}$, o nome foi utilizado pela primeira vez em A Fisionomia do Rio Grande do Sul - Ensaio de monografia natural, obra que granjeou merecida fama ao botânico gaúcho e cuja primeira edição ${ }^{8}$ data de 1942.

Como visto em artigo anterior ${ }^{9}$, Balduíno Rambo visitou o extremo sudoeste do estado

6 Com área original de 276 ha, o Parque Estadual do Espinilho foi criado pelo Decreto ${ }^{\circ} 23.798$ do Governo do Estado do Rio Grande do Sul, em 12/3/1975. Em $28 / 2 / 2002$, a sua área foi ampliada para $1.617,14$ ha, pelo Decreto Estadual n ${ }^{\circ} 41.440$.

7 Antes de Rambo, Lindman havia utilizado o termo parque espinillo uma única vez, na legenda de uma ilustração reproduzida no presente artigo (Figura 1). O botânico sueco, todavia, deixa claro sua preferência pelo termo pasto espinillo.

8 RAMBO, B. A fisionomia do Rio Grande do Sul - Ensaio de monografia natural. Porto Alegre: Of. Graf. da Imprensa Oficial, 1942. 360 p.

9 MARCHIORI, J.N.C.; ALVES, F. da S.; DEBLE, L.P.; DEBLE, A.S. de O. A vegetação no Parque Estadual do 
uma única vez, em 15 de janeiro de 1941, - e por poucas horas -, no intervalo entre a chegada do trem à estação de Barra do Quaraí e seu retorno a Uruguaiana ${ }^{10}$. Das espécies arbóreas observadas na região, o autor destaca Prosopis affinis ${ }^{11}$, por ele chamado de "algarrobo", e Vachellia caven ${ }^{12}$, designada como "nhanduvaî". Além do evidente equívoco com os nomes populares de ambas as espécies, o que mais chama atenção, na obra de Rambo, é a ausência do nome comum "espinilho" na lista de espécies arbóreas, posto ser este o nome atribuído a Vachellia caven, tanto no linguajar regional como pela literatura especializada ${ }^{13}$.

Esta ausência se torna ainda mais evidente quando se observa que Lindman, autor de $A V e$ getação no Rio Grande do Sul, registra o espinillo (Acacia farnesiana) como espécie prin-

Espinilho. 1 - Histórico da ocupação humana e evolução do conhecimento botânico e fitogeográfico sobre o Pontal do Quaraí. Balduinia, Santa Maria, n. 43, p. 128, 2013.

${ }^{10}$ Balduíno Rambo saiu de Uruguaiana pela manhã e retornou a essa cidade ao final da tarde do mesmo dia. Ao leitor interessado, recomenda-se: MARCHIORI et al., 2013. Op. cit., p. 10-11.

${ }^{11}$ Rambo valeu-se de dois binômios para a espécie, em sua obra-prima: Prosopis juliflora, na edição de 1942, e Prosopis algarobilla, na de 1956. No caso de Prosopis juliflora, trata-se de espécie distinta; o binômio Prosopis algarobilla, por sua vez, acabou reduzido à sinonímia de Prosopis affinis.

${ }^{12}$ Rambo valeu-se, em verdade, do binômio Acacia farnesiana para a espécie, em ambas as edições por ele examinadas de sua obra-prima (1942 e 1956). Resta acrescentar que a edição póstuma (RAMBO, B. 2005) não introduziu qualquer reparo nessa questão.

${ }^{13}$ Antonio Krapovickas, sobre esse tema, informa que o camponês usa os seguintes nomes na província argentina de Corrientes: "Espinillo Santa Fé" (=Acacia caven) y "Espinillo" (= Prosopis affinis, árbol vivo) y "ñandubay"(= Prosopis affinis, madera, leña). Si señor!, Prosopis affinis tiene dos nombres, uno para el árbol vivo y otro para la madera del árbol muerto! Esto lo comprobamos aquí en la ciudad de Corrientes y en el centro de la província de Corrientes, en Mburucuyá, gracias a T. M. Pedersen, uma fuente muy seria. Yo mismo lo oí varias veces en el campo". No Rio Grande do Sul, todavia, o nome espinilho é invariavelmente aplicado à Vachellia caven, e o de inhanduvá à Prosopis affinis. cipal do pasto espinillo, vegetação por ele examinada nos arredores de Monte Caseros, cidade argentina situada quase em frente à Barra do Quaraí. O botânico sueco, aliás, menciona apenas de passagem - e em nota de rodapé -, que sob o nome espinillo também se contam "às vezes (...) algumas espécies de Prosopis" de folhas pequenas ${ }^{14}$. Cumpre salientar, ainda, que na legenda de uma ilustração constante em sua obra $^{15}$, Lindman refere-se, à mesma, como parque espinillo (Figura 1), termo adotado por Balduíno Rambo na primeira edição de $A$ Fisionomia do Rio Grande do Sul, mediante o simples aportuguesamento do nome comum de Vachellia caven (espinilho).

O que causa estranheza, no texto do sueco, é o não reconhecimento da dominância do inhanduvá (Prosopis affinis) na vegetação dos parques por ele avistados (e/ou examinados) na Mesopotâmia argentina, posto ser essa a espécie mais importante para a fisionomia e estrutura dos mesmos. Sobre este ponto, todavia, devese levar em conta que o visitante esteve na região em rigoroso inverno, ${ }^{16}$ e que a identificação se torna mais difícil em árvores desprovidas de "grande parte dos folíolos", conforme registro do próprio autor. Para Lindman, a "cor viva verde-bruna" dos pecíolos conferia às árvores o aspecto de "pinheirinho dos brejos boreais". ${ }^{17}$

A mesma comparação se encontra, basicamente, no texto do botânico gaúcho ${ }^{18}$. Rambo, todavia, esteve em Barra do Quaraí no mês de

${ }^{14}$ LINDMAN, C.A.M. A vegetação no Rio Grande do Sul (Brasil Austral). Porto Alegre: Typographia da "Livraria Universal” de Echenique Irmãos \& Cia, 1906. p. 112. As palavras do autor sueco coincidem com a informação de Krapovickas, transcrita na nota anterior, e enviada, por e-mail, ao primeiro autor do presente artigo.

${ }^{15}$ LINDMAN, 1906. Op. cit., p. 113.

16 "Durante a minha estada ali, todas as manhãs viam-se os campos brancos de geada" (LINDMAN, 1906. Op. cit., p. 109).

${ }^{17}$ LINDMAN, 1906. Op. cit., p. 112.

18 "O caráter geral lembra, à primeira vista, algum pinheiro anão atormentado pelas intempéries do frio polar (...)." (RAMBO, B., 1942. Op. cit., p. p. 105). 


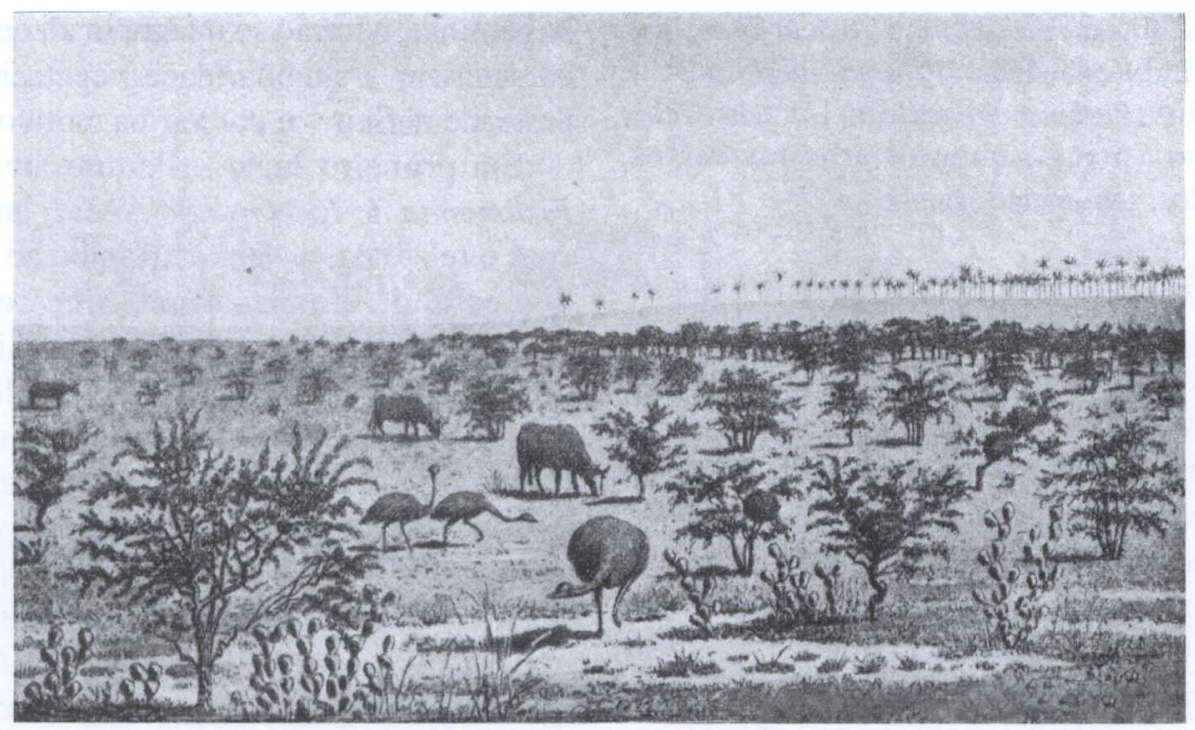

FIGURA 1 - Paisagem de um "Parque Espinillo" da parte norte da província argentina de Entre Rios (Junho de 1903), com algumas emas (Rhea americana) e bovinos no primeiro plano, em meio a um campo com arumbevas (Opuntia elata), arvoretas espinhosas, e o típico palmar de Butia yatay na linha do horizonte. De: LINDMAN, 1906. Op. cit., p. 118.

janeiro, em plena floração de Prosopis affinis $^{19}$, motivo pelo qual ele pode reconhecer a dominância da espécie ${ }^{20}$ na estrutura da vegetação. ${ }^{21} \mathrm{O}$ equívoco de Rambo reside, basicamente, no nome atribuído às duas árvores chaquenhas: Vachellia caven foi chamada de "nhanduvấ", e Prosopis affinis de "algarrobo".

O termo "espinilho", utilizado por Lindman tanto para a tipologia da vegetação (pasto espinillo, parque espinillo), como nome comum de uma espécie de $\mathrm{Acacia}^{22}$, foi reservado pelo fitogeógrafo gaúcho, em sua obra-prima, para

19 "Os Algarrobos agradam-me de modo especial. Sobem a mais de sete metros, ostentando belas copas em forma de guarda-chuva. Estão em flor." (RAMBO, A. B. Viagem de Balduíno Rambo ao sudoeste do Rio Grande do Sul no ano de 1941. Balduinia, Santa Maria, n. 36, p. 25, 2012).

${ }^{20}$ Sob o equivocado nome comum de "algarrobo", Rambo identificou a espécie como Prosopis juliflora na edição de 1942, e como Prosopis algarobilla na de 1956.

21 "O parque espinilho, resultante da sociedade de Prosopis e Acacia, (...)." (RAMBO, B., 1942. Op. cit., p. 105).

${ }^{22}$ Lindman identificou a espécie como Acacia farnesiana; trata-se, todavia, de Vachellia caven. designar, tão somente, vegetações semelhantes à descrita pelo sueco.

A respeito da identidade das árvores chaquenhas, resta informar que Rambo deu-se conta dos erros cometidos em A Fisionomia do Rio Grande do Sul, posto que no relatório sobre a "indústria lítica de Quaraî", vindo a lume em 1946, o parque existente ao sul do Jarau ${ }^{23}$ foi descrito como composto

${ }^{23}$ Não se pode confundir a vegetação de parque, referida neste artigo, com o Espinillal examinado pelo autor em 1941, na orla da mata ciliar do rio Quaraí-Mirim. O parque de inhanduvá, descrito por Rambo em 1946, se encontra em lente de solos francamente arenosos, com cerca de 5,5 km de diâmetro, situada ao sul do Jarau, e drenada pelo Arroio Inhanduvá. Na viagem de 1941, Rambo não esteve nessa área, pois cruzou pelo Rio Quaraí-Mirim mais a leste, em seu deslocamento, de táxi, entre as cidades de Quaraí e Uruguaiana. Na orla da mata ciliar do Quaraí-Mirim não se encontram inhanduvás. Resta informar que a ocorrência natural da espécie, no município de Quaraí, consta em relatório manuscrito de 1903, firmado pelo intendente: "a fauna é pobre e nenhuma especie della é digna de nota por não sahir do vulgar, bem como a flora, de que não se destaca nenhum especimen de valor. Existe algum inhanduvá entre costas do Quarahy e cerros de Jarau em 
“essencialmente de espinilho (Acacia farnesiana (L.) Willd.), nhandubai (Prosopis juliflora DC.), cina-cina (Parkinsonia aculeata L.), tala (Celtis spinosa Spreng.) e outros arbustos baixos, xerófilos, geralmente espinhosos". ${ }^{24}$

No texto acima transcrito, vê-se, claramente, que Balduíno Rambo não mais confunde a identidade das duas Leguminosas, chamandoas pelos verdadeiros nomes comuns (espinilho e inhanduvá ou nhandubai, respectivamente). Os lapsos com os epítetos específicos ${ }^{25}$ podem ser debitados, desta vez, ao difícil acesso à literatura botânica, aspecto muito saliente naquela época. É de se lastimar, todavia, que o autor não tenha revisto adequadamente o texto da segunda edição de A Fisionomia do Rio Grande do Sul, vinda a lume no ano de 1956 . Se o tivesse feito, as confusões anteriormente apontadas não teriam sobrevivido até a atualidade e, muito provavelmente, a leitura descuidada deste verdadeiro clássico da literatura sulina não teria fornecido o falso embasamento implícito na designação oficial da unidade de conservação em foco: "Parque Estadual do Espinilho".

Ocorre que o termo "Parque Espinilho" firmou-se na linguagem botânica e fitogeográfica do Rio Grande do Sul por dar nome, justamente, a essa unidade de conservação. Embora criado por Balduíno Rambo, a partir de uma referência de Lindman sobre vegetação examinada nos arredores de Monte Caseros (Corrientes,

forte vertente que tira o nome da existência nella daquella madeira." (CUNHA, F.F. da. Apontamentos históricos e informações geraes sobre o município de Quarahy compilados em 1903 pelo Intendente Cel. Francisco Flores da Cunha. In: CHEGUHEM, S.S. Quaraí Histórico. Quaraí: [s.n.], 1991. v. 2. p. 34.

${ }^{24}$ RAMBO, B. Relatório científico das viagens de estudos etnográficos, empreendidas entre 26 de dezembro de 1944 e 14 de março de 1945, pelo P. Balduíno Rambo S. J., lente de Etnografia e Etnologia da Faculdade de Filosofia da Universidade de Porto Alegre. Revista do Instituto Histórico e Geográfico do Rio Grande do Sul, Porto Alegre, n. 102, p. 235, 1946.

${ }^{25}$ Em verdade, o inhanduvá corresponde a Prosopis affinis, e o espinilho a Vachellia caven.
Argentina), o termo se mostra inadequado para caracterizar a singularidade vegetacional que pretende definir - e por vários motivos.

Em primeiro lugar, a leitura atenta de $A$ Fisionomia do Rio Grande do Sul, juntamente com o relato da viagem de Rambo ao sudoeste do estado, demonstram que o termo fitogeográfico padece de grave imprecisão, uma vez que o botânico gaúcho valeu-se do mesmo para designar tanto o parque de inhanduvás de Barra do Quaraí, composto, fundamentalmente, por Prosopis affinis e Vachellia caven, como o parque de espinilhos do Quaraí-Mirim (Figura 2), baseado em Vachellia caven (espinilho), mas desprovido de inhanduvás (Prosopis affinis). Nos textos em espanhol, a primeira destas tipologias é comumente dita Ñandubaysal, ao passo que a segunda corresponde ao Espinillal.

Foi o "grande gregarismo" das espécies de Prosopis nos arredores de Barra do Quaraí, que levou os autores ${ }^{26}$ do Projeto Madeira do Rio Grande do Sul a considerar mais adequado o termo Parque do Inhanduvaí para a vegetação ali encontrada, opinião defendida em artigos posteriores $^{27}$. Ocorre que as tipologias de vegetação costumam ser designadas com base na espécie característica. Segundo este princípio, aos parques de Barra do Quaraí caberia o nome de "Parque de Inhanduvá", e aos formados, basicamente, por Vachellia caven, o de "parque espinilho".

Verdadeiros parques de espinilhos (ou Espinillares), como o examinado por Rambo na orla da mata ciliar do Rio Quaraí-Mirim, no município de Quaraí, apresentam ampla distribuição nas áreas campestres do Estado, sobretudo nas regiões fisiográficas da Campanha, Serra do Sudeste, Depressão Central e Planalto Médio, devido ao fato de Vachellia caven, a sua espé-

\footnotetext{
${ }^{26}$ REITZ, R.; KLEIN, R.M.; REIS, A. Projeto Madeira do Rio Grande do Sul. Sellowia, Itajaí, n. 34-35, p. 12 13,1983

27 "Parque de Inhanduvá", segundo MARCHIORI, LONGHI \& GALVÃO (1985a, b), entre outros.
} 


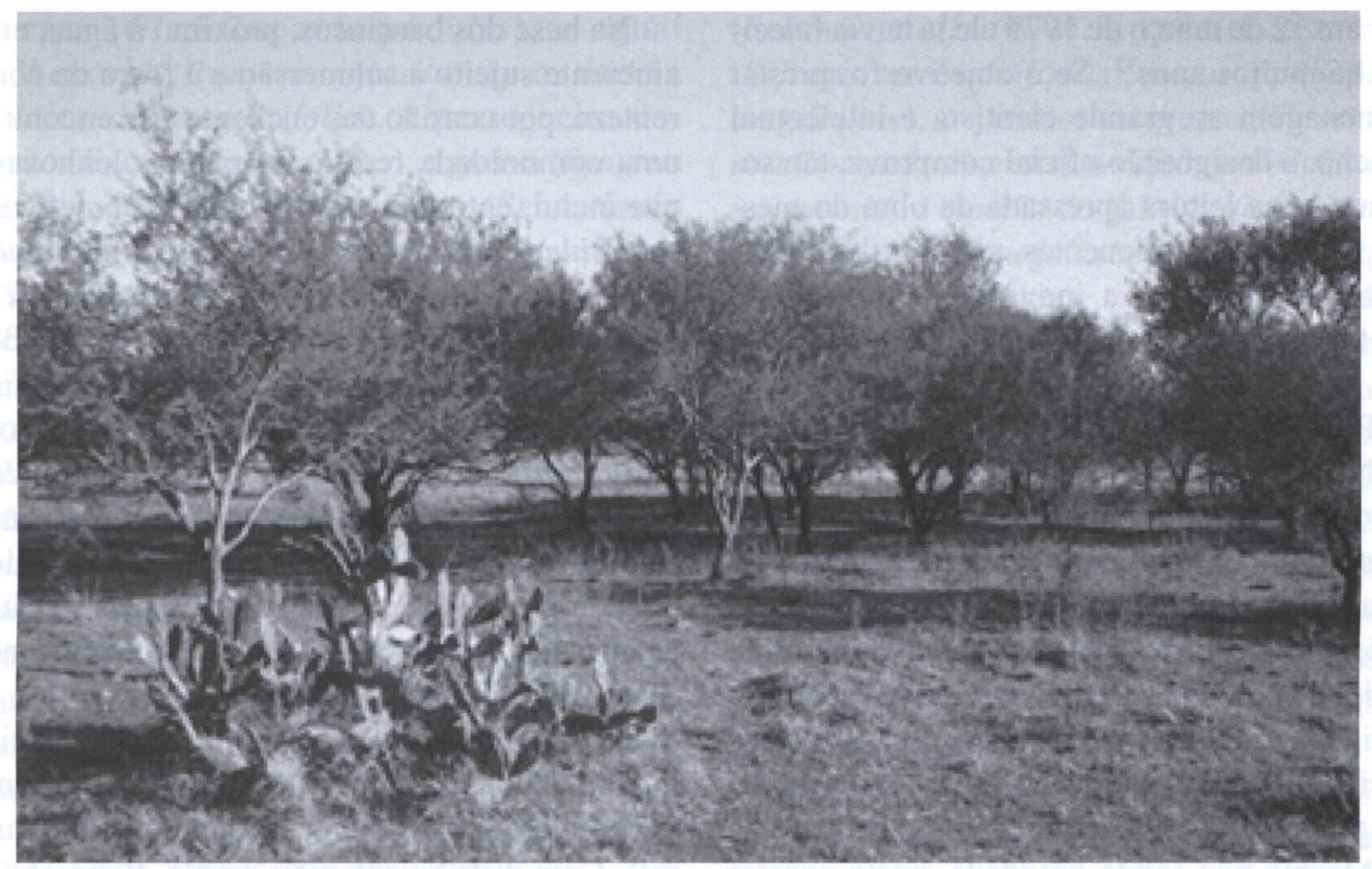

FIGURA 2 - Aspecto geral de um parque de espinilhos junto à mata ciliar do Rio Quaraí-Mirim (Quaraí, RS), tipologia observada por Balduino Rambo em janeiro de 1941, em sua viagem entre as cidades de Quaraí e Uruguaiana. Composta, basicamente, por indivíduos de Vachellia caven (espinilho), a vegetação carece de inhanduvás (Prosopis affinis).

cie característica, não estar vinculada a formações sedimentares, ao contrário do inhanduvá (Prosopis affinis).

A hipótese do termo "parque espinilho" ser uma referência à Província do Espinal, aventada por Galvani (2003), não se sustenta, e por mera impossibilidade histórica: criado por Ángel Lulio Cabrera, esse termo fitogeográfico somente entrou na literatura nove anos após ${ }^{28}$ a primeira edição de A Fisionomia do Rio Grande do Sul. Antes disso, os termos zona de los espinares ou espinares ${ }^{29}$ já constavam em arti-

${ }^{28}$ CABRERA, A.L. Territórios fitogeográficos de la Republica Argentina. Boletín de la Sociedad Argentina de Botánica, v. 4, n. 1-2, p. 21-65, 1951.

${ }^{29}$ A palavra espinares, em espanhol, é plural do termo espinal (espinhal, em português).

${ }^{30}$ HIERONYMUS, D.J. Observaciones sobre la vegetación de la Província de Tucuman. Boletín de la Academia Nacional de Ciencias Exactas existente en la go fitogeográfico do século $\mathrm{XIX}^{30}$, mencionado por Lindman ${ }^{31}$, mas foram atribuídos a um tipo de vegetação da província argentina de Tucumán, sem a abrangência revelada pelos estudos de Cabrera.

Balduino Rambo foi, indiscutivelmente, o mais importante botânico e fitogeógrafo do Rio Grande do Sul no século vinte. Eventuais lapsos, em sua vasta obra, não descuram, de modo algum, o seu merecido e perene renome de cientista. A seu favor, ainda, deve-se levar em conta as limitações de toda a ordem, inevitáveis no tempo que lhe coube viver.

Embora autor do termo "Parque Espinilho", Balduíno Rambo não é, certamente, responsável pelo nome da unidade de conservação criada pelo governo do estado do Rio Grande do Sul no município de Barra do Quaraí, uma vez

Universidad de Cordova, Buenos Aires, v. 1, p. 183234, 1874.

${ }^{31}$ LINDMAN, 1906. Op. cit., p. 114. 
que em 12 de março de 1975 ele já havia falecido, há muitos anos ${ }^{32}$. Se o objetivo foi prestar homenagem ao grande cientista e intelectual gaúcho, a designação oficial comprova, tão somente, uma leitura apressada da obra do mestre, feita pelos proponentes, pois resulta descabida - e injusta - a inevitável notoriedade conferida a um de seus raros equívocos.

\section{ASPECTOS FITOGEOGRÁFICOS}

$\mathrm{Na}$ área do Parque Estadual do Espinilho se encontram três tipologias básicas de vegetação (mata ciliar, parque de inhanduvá e parque de algarrobo), além de uma diversificada comunidade de macrófitas aquáticas. Apesar de a flórula regional não ser objeto do presente artigo, a designação das principais espécies se mostra indispensável à caracterização botânica e fitogeográfica das distintas tipologias.

Mesmo não sendo novidade, posto constar na literatura desde os trabalhos pioneiros de Marchiori, Longhi \& Galvão (1985a, b), o reconhecimento de duas tipologias silvático-campestres $^{33}$ é uma necessidade que se impõe pelas diferenças marcantes entre os parques de inhanduvá e de algarrobo, seja pelas condições ambientais ou pela flórula envolvida.

\section{1 - Mata ciliar}

As matas ciliares ou em galeria compõem uma faixa paralela ao Rio Uruguai, no extremo oeste da unidade de conservação, bem como ao longo do Arroio Quaraí-Chico, sobretudo em seu curso final, de caráter nitidamente meândrico. Trata-se de fragmento de floresta aluvial muito representativo da tipologia, graças à preservação assegurada, tanto pela criação do Parque Estadual do Espinilho, como pelo difícil acesso à área.

\footnotetext{
${ }^{32}$ Balduíno Rambo faleceu em Porto Alegre, a 12 de setembro de 1961, quase catorze anos antes da criação do Parque Estadual do Espinilho.

${ }^{33}$ Expressão utilizada por Balduíno Rambo, em sua definição do "Parque Espinilho".
}

Na base dos barrancos, próximo à água, em ambiente sujeito à submersão e à força da correnteza, por ocasião das enchentes, se encontra uma comunidade reófila de plantas lenhosas, que inclui, entre outras: o sarandi (Sebastiania schottiana), o sarandi-vermelho (Phyllanthus sellowianus), o amarilho (Terminalia australis), o mata-olho (Pouteria salicifolia), o angiquinho (Calliandra brevipes), o salseiro (Salix humboldtiana), o marmeleiro-da-beira-de-rios (Ruprechtia salicifolia), e o timbó-branco (Albizia inundata). Destas, cabe destacar que as duas últimas são pouco conhecidas no Rio Grande do Sul, por terem distribuição restrita às matas ciliares do rio Uruguai e afluentes, no Sudoeste do Estado.

No caso de Albizia inundata, a ocorrência no Pontal do Quaraí mereceu publicação recen$t^{34}$, esclarecendo dúvida constante na literatu$\mathrm{ra}^{35}$. Com distribuição mais ampla, Ruprechtia laxiflora ocorre, naturalmente, nas matas ciliares do curso médio e inferior do Rio Uruguai e afluentes, em ambientes menos restritivos sob o ponto de vista da reofilia ${ }^{36}$, à semelhança do sangue-de-dragão (Croton urucurana), e de uma espécie de juquiri (Mimosa pigra).

No alto dos barrancos, dominam ingazeiros (Inga vera), juntamente com espécies da Floresta Estacional, entre as quais, salientam-se: a canafístula (Peltophorum dubium), o açoita-cavalo (Luehea divaricata), o angico-vermelho (Parapiptadenia rigida), o ipê-roxo (Handroanthus heptaphyllus), a guajuvira (Cordia americana), o umbu (Phytolacca dioica), o camboatá-vermelho (Cupania vernalis), o

${ }^{34}$ MARCHIORI, J.N.C.; ALVES, F. da S. Nota sobre a ocorrência natural de Albizia inundata (Mart.) Barneby \& Grimes no Rio Grande do Sul. Balduinia, Santa Maria, n. 33, p. 21-25, 2012b.

${ }^{35}$ A "Flora arbórea e arborescente do Rio Grande do Sul" informa que não "foi possível examinar nenhuma coleta desta espécie proveniente do Rio Grande do Sul" (SOBRAL et al., 2006, Op. cit., p. 113).

${ }^{36}$ MARCHIORI, J.N.C.; SABIN, L. dos S. Identificação botânica de Ruprechtia salicifolia (Cham. \& Schltdl.) C.A. Mey. Balduinia, Santa Maria, n. 20, p. 4, 2010. 
sucará (Gleditsia amorphoides), o aguaí (Chrysophyllum marginatum), a canela (Nectandra angustifolia), o pessegueiro-domato (Eugenia myrcianthes), o gerivá (Syagrus romanzoffiana), o branquilho (Sebastiania commersoniana), o branquilho-leiteiro (Sebastiania brasiliensis), a pata-de-vaca (Bauhinia forficata), a pitangueira (Eugenia uniflora), a pitanga-amarga (Eugenia mansoi), a murta (Blepharocalyx salicifolius), o murtilho (Myrrhinium atropurpureum), o guamirim (Eugenia uruguayensis), o araçá (Myrcianthes cisplatensis), o chal-chal (Allophylus edulis), o rabo-de-bugio (Lonchocarpus nitidus), e dois camboins (Myrcia selloi, Eugenia repanda). No sub-bosque, destacam-se: a embira (Daphnopsis racemosa), e a juruvarana (Psychotria carthagenensis).

No caso da canafístula (Peltophorum dubium), o registro pioneiro na região se deve a Atílio Lombardo, botânico que assinalou a ocorrência natural da espécie no noroeste do Uruguai. ${ }^{37} \mathrm{Na}$ região do Pontal do Quaraí, a primeira referência a este ornamento conspícuo da mata ciliar se deve a Galvani (2003). A dispersão da espécie mereceu publicação recente, dando conta que os legumes samaróides, levados inicialmente pelo vento, acabam por ser transportados pelas águas, rio abaixo, sendo comumente encontrados no alto dos barrancos, junto a detritos deixados pelas enchentes. ${ }^{38}$

$\mathrm{Na}$ orla da mata predominam arvoretas, arbustos e lianas, tais como: o carvalhinho (Casearia silvestris), a coronilha (Scutia buxifolia), a taleira (Celtis iguanaea), o fumobravo (Solanum mauritianum), a aroeira-brava

${ }^{37}$ LOMBARDO, A. Noticia de la vegetación de la costa oriental del rio Uruguay en los departamentos de Paysandu, Salto e Artigas. Comunicaciones Botánicas del Museo de Historia Natural de Montevideo, n. 4, p. $4,1943$.

${ }^{38}$ MARCHIORI, J.N.C.; ALVES, F. da S. Nota sobre a distribuição geográfica de Peltophorum dubium (Spreng.) Taub. no Rio Grande do Sul. Balduinia, Santa Maria, n. 33, p. 30, 2012c.
(Schinus molleoides), a aroeira-vermelha (Schinus terebinthifolius), o curupi (Sapium longifolium), o jasmim-catavento (Tabernaemontana catharinensis), o veludinho (Guettarda uruguensis), o esporão-de-galo (Celtis iguanaea), a unha-de-gato (Senegalia bonariensis), o juquiri (Mimosa uraguensis), o topete-de-cardeal (Calliandra tweediei), a cancorosa (Maytenus muelleri), a japecanga (Smilax campestris), a escova-de-macaco (Combretum fruticosum), a coerana-amarela (Cestrum fruticosum), a clematite (Clematis montevidensis), o cipó-timbó (Paullinia elegans), e o maracujá-azul (Passiflora caerulea).

$\mathrm{Na}$ orla de pântanos, predominam: a corticeira (Erythrina cristagalli), uma espécie de sarandi (Cephalanthus glabratus), e a laranjeira-do-banhado (Citronella gongonha).

Das epífitas, salientam-se quatro Pteridófitas (Microgramma mortoniana, Microgramma vacciniifolia, Pleopeltis pleopeltifolia, Pleopeltis squalida), quatro Bromeliáceas (Tillandsia aeranthos, Tillandsia geminiflora, Tillandsia recurvata, Tillandsia usneoides), e uma orquídea (Oncidium bifolium).

Resta informar que, sob o ponto de vista fitogeográfico, a mata ciliar do Parque Estadual do Espinilho pode ser classificada como Floresta Estacional Decidual Aluvial.

\section{2 - Parque de Inhanduvá}

O Parque de Inhanduvá propriamente dito corresponde à vegetação descrita por Balduíno Rambo $^{39}$ sob o nome de "Parque Espinilho" em Barra do Quaraí: uma associação baseada em Prosopis affinis (inhanduvá) e Vachellia caven (espinilho) no estrato superior, com um denso e diversificado estrato herbáceo, em que predominam Poáceas, Asteráceas e Fabáceas. As duas espécies mencionadas crescem isoladas ou em pequenos grupos, e são arvoretas paucifoliadas,

39 "São principalmente duas espécies de leguminosas mimosoídeas, que determinam o aspecto curioso destes parques espinhosos e sêcos: o algarrobo (Prosopis juliflora) e o nhanduvaí (Acacia farnesiana)" (RAMBO, B., 1942. Op. cit., p. 104). 
permitindo o desenvolvimento do denso tapete herbáceo (Figura 3).

Tipologia dominante na unidade de conservação, o Parque de Inhanduvás propriamente dito encontra-se em toda a área situada a leste da BR 472, bem como em larga faixa a oeste da mesma, ocupando terrenos relativamente altos e de solos menos salinos do que os do Algarrobal ou Parque de Algarrobos. A vegetação se mostra melhor conservada no extremo leste da unidade de conservação, em pontos mais distantes de caminhos e, sobretudo, da BR 472, que funciona como "porta de entrada" para espécies invasoras. Nessa situação, mais de $85 \%$ da vegetação arbórea do parque é composta por indivíduos de Prosopis affinis, cabendo ao espinilho (Vachellia caven) um papel nitidamente coadjuvante. É por este motivo, aliás, que essa tipologia de parque é geralmente definida como $\tilde{N}$ andubaysal, na literatura do Uruguai e Argentina. Cabe salientar que ali não se encontram o quebracho-branco (Aspidosperma quebrachoblanco), o algarrobo (Prosopis nigra), e um numeroso contingente de ervas endêmicas.

Em decorrência de ações antrópicas variadas, a participação do espinilho e de outras plantas lenhosas tende a crescer, chegando a ser expressiva no trecho adjacente à referida rodovia, de modo a incluir, entre outras: a taleira (Celtis ehrenbergiana), o garupá (Aloysia gratissima), a coronilha (Scutia buxifolia), o curupi (Sapium haematospermum), e o molho (Schinus polyygamus).

O caráter xerófilo da vegetação é ressaltado, fisionomicamente, pela abundância de espinhos na maioria das espécies relacionadas, aspecto reforçado pela arumbeva (Opuntia elata) e pela tuna (Cereus hildmannianus), duas cactáceas conspícuas na vegetação. Outras duas espécies da mesma família recebem o nome comum de rabo-de-rato, habitando em troncos e ramos grossos de inhanduvás: Lepismium aculeata e Lepismium lumbricoides. No grupo das epífitas, salientam-se, ainda, outras três Pteridófitas (Microgramma mortoniana,
Pleopeltis pleopeltifolia, Pleopeltis squalidum) e Tillandsia duratii, entre outros cravos-do-mato (Bromeliaceae). Das lianas, destacam-se Dolichandra cynanchoides, Passiflora caerulea e Gonolobus rostratus. Das hemiparasitas, $\mathrm{Li}$ garia cuneifolia vive sobre o espinilho, e Struthantus uraguensis em Prosopis affinis. Embora incompleta, essa lista de espécies já basta para a caracterização sumária da flórula do Parque de Inhanduvás propriamente dito, de Barra do Quaraí.

Resta salientar que essa tipologia, embora descrita em 1985, não é reconhecida como distinta do Parque de Algarrobos pela maioria dos autores que escreveram sobre o Parque Estadual do Espinilho. Por fim, cabe salientar que essas unidades ${ }^{40}$, além de inconfundíveis sob os pontos de vista fitoecológico e florístico, também ocupam áreas distintas na unidade de conservação, e que o limite entre ambas é de fácil reconhecimento na natureza.

\section{3 - Parque de Algarrobos ou Algarrobal}

$\mathrm{Na}$ área do Parque Estadual do Espinilho, o Algarrobal ou Parque de Algarrobos se encontra apenas a oeste da BR 472, situando-se entre o Parque de Inhanduvás propriamente dito, e as matas ciliares do Rio Uruguai e Arroio QuaraíChico. Desconhecida até 1985 , pela literatura fitogeográfica brasileira ${ }^{41}$, a tipologia ocupa terrenos ainda mais planos e de menor altitude do que os do Parque de Inhanduvá propriamente dito, motivo pelo qual, na unidade de conservação, a sua área é eventualmente alagada em grandes enchentes.

No tocante ao solo, a alta concentração de sais na superfície explica a rarefação da cobertura vegetal em manchas irregulares, explicando o termo blanqueales, com que os uruguaios e argentinos a designam, em alusão ao tom esbranquiçado do solo desnudo em períodos de

\footnotetext{
${ }^{40}$ Referimo-nos aos Parques de Inhanduvá e de Algarrobo.

${ }^{41}$ No Rio Grande do Sul, a tipologia foi originalmente descrita por MARCHIORI, LONGHI \& GALVÃO (1985b).
} 


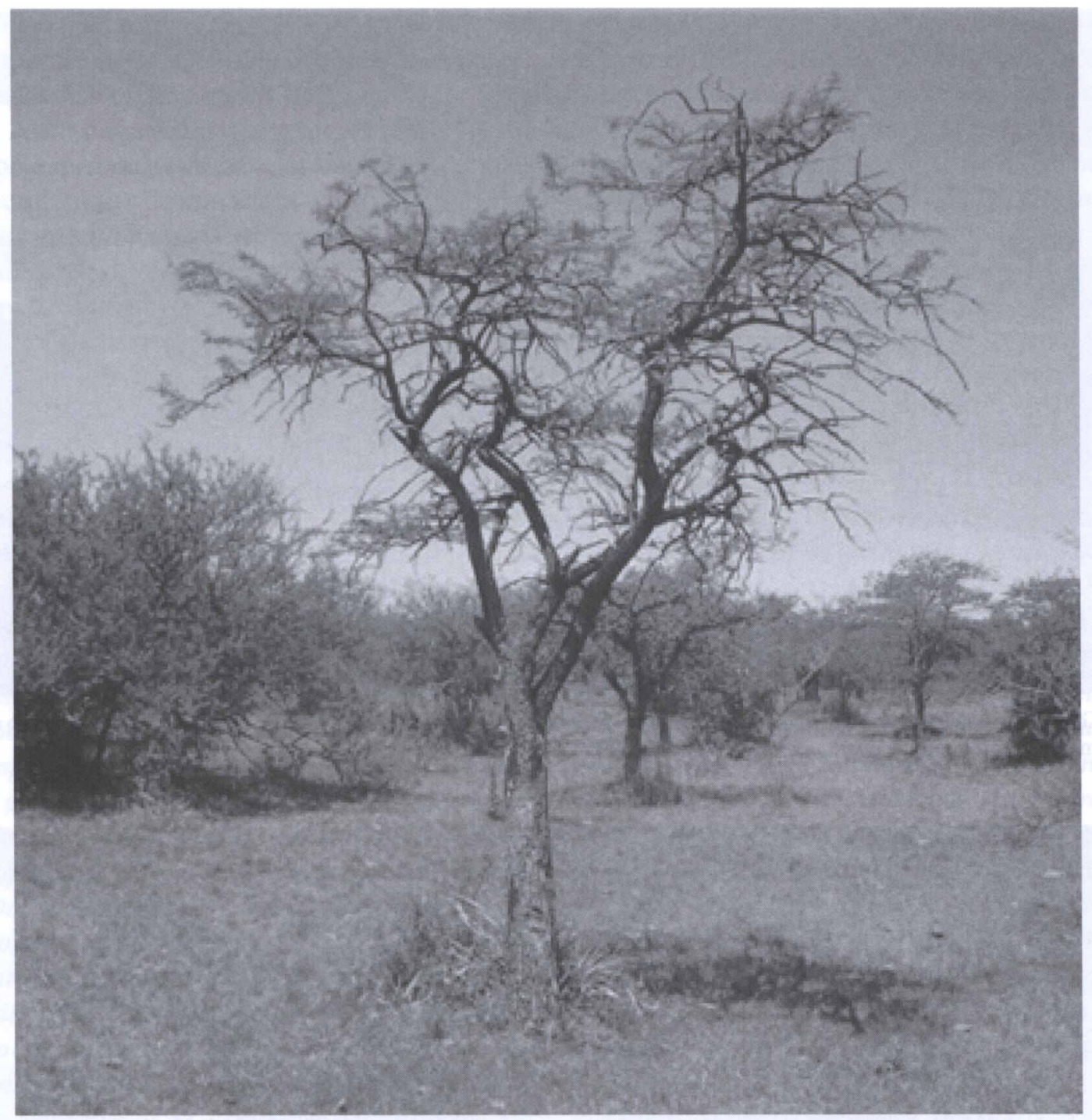

FIGURA 3 - Aspecto do Ñandubaysal ou Parque de Inhanduvás propriamente dito, tipologia predominante na área do Parque Estadual do Espinilho. Trata-se da vegetação examinada por Balduíno Rambo em Barra do Quaraí, em sua viagem de Janeiro de 1941 (Foto: Victoria Rosenthal, 19 de dezembro de 2013).

seca (Figura 4). Aessa elevada salinidade é que se deve, ainda, a presença de numerosas halófitas em sua diversificada flora endêmica.

Sob o ponto de vista estrutural, as árvores são mais distanciadas entre si e, no caso do quebracho (Aspidosperma quebrachoblanco), também mais altas do que o verificado no Parque de Inhanduvás propriamente dito, dando origem a uma fisionomia mais aberta (Figura 5).
No que diz respeito à florística, observa-se nítida predominância de Prosopis nigra (algarrobo) na estrutura da vegetação, espécie ausente na tipologia anteriormente examinada, à semelhança do quebracho-branco (Aspidosperma quebrachoblanco).

De um total de 339 árvores medidas no primeiro estudo sobre o Algarrobal no Rio Grande do Sul, 107 eram de Prosopis nigra, 87 de 


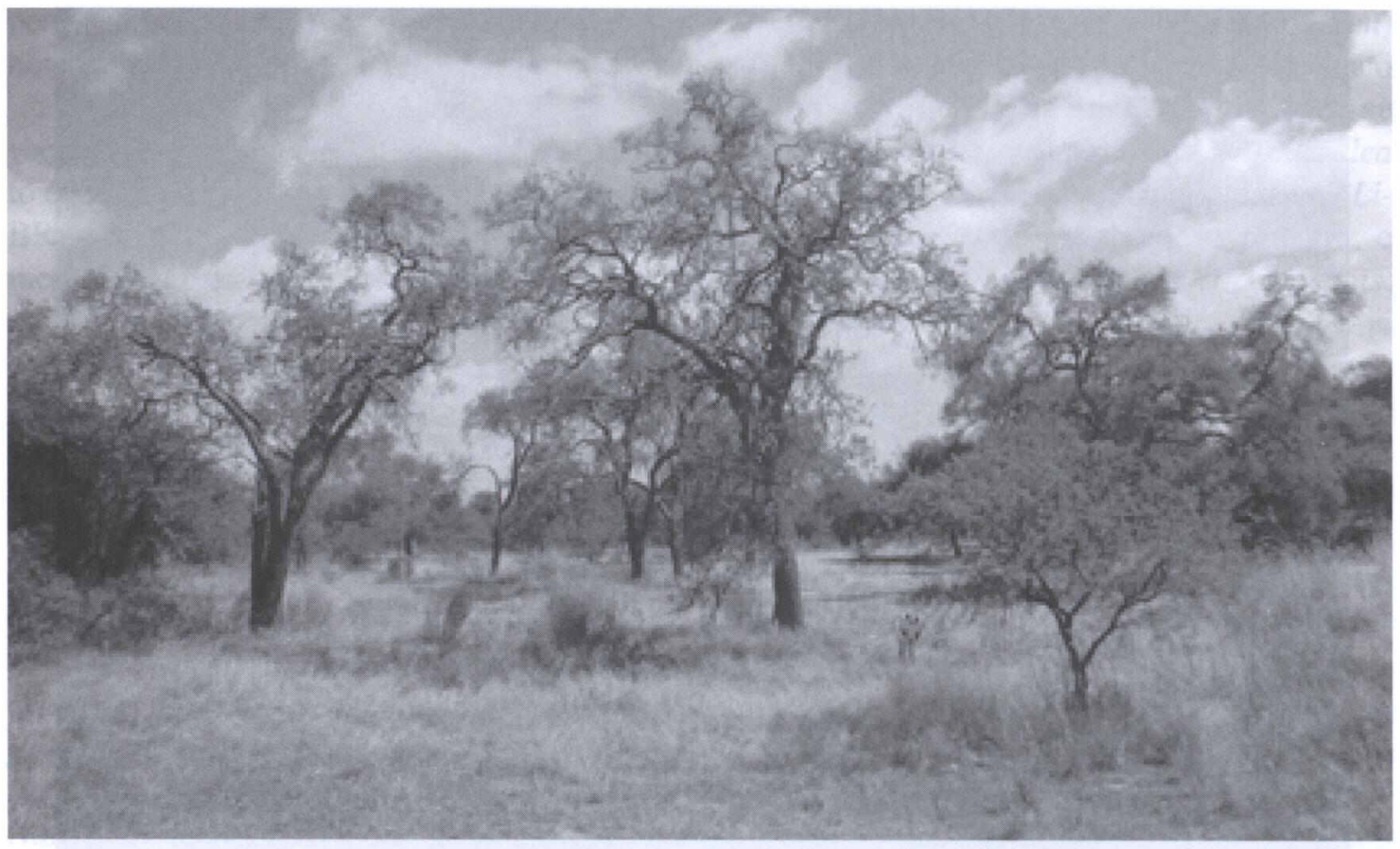

FIGURA 4 - Aspecto geral do Algarrobal do Parque Estadual do Espinilho, destacando as manchas de solo desnudo ou com vegetação rarefeita (blanqueales), em primeiro plano.

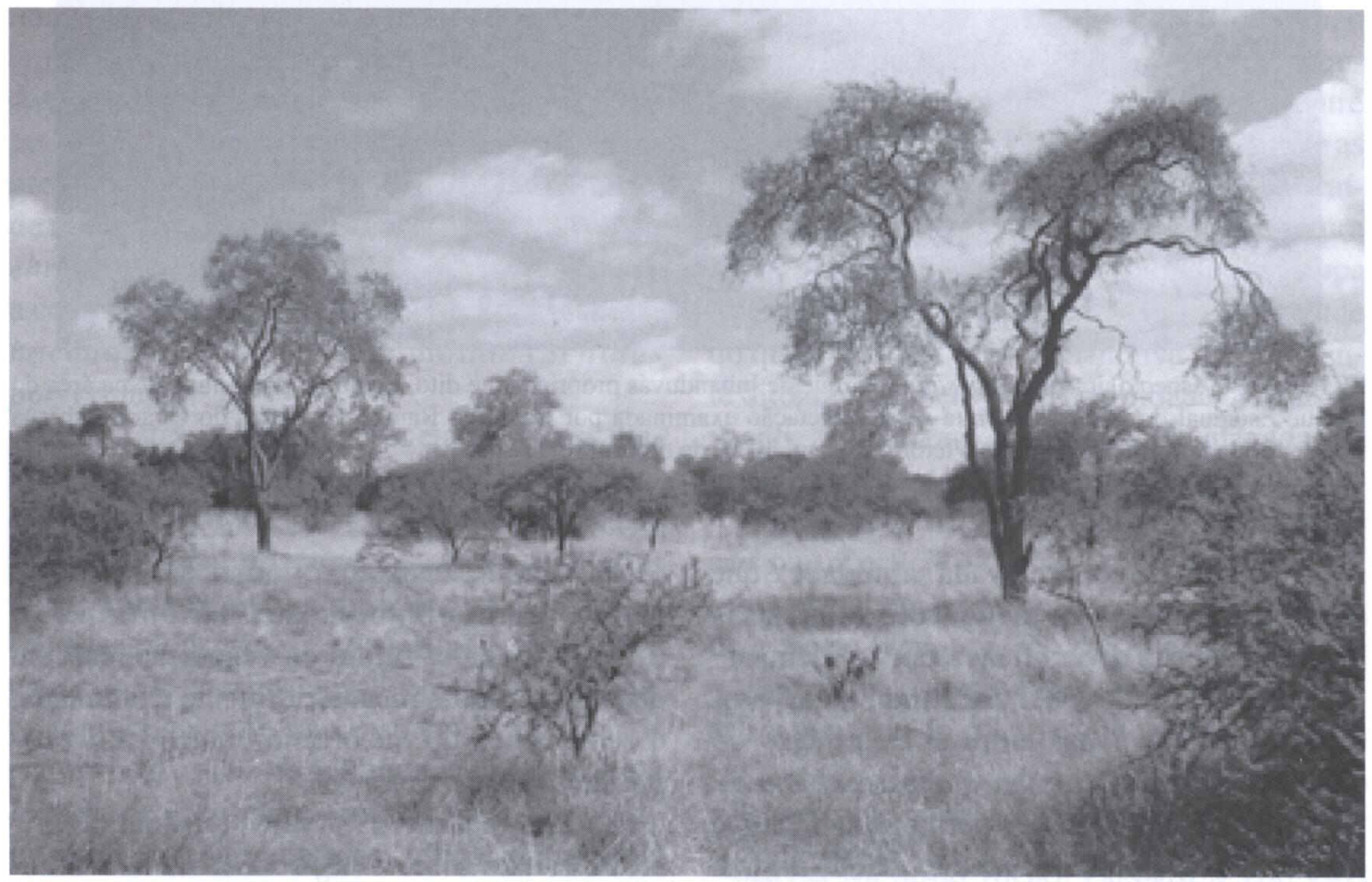

FIGURA 5 - Aspecto geral do Algarrobal do Parque Estadual do Espinilho; as árvores de maior porte são quebrachos (Aspidosperma quebrachoblanco, Apocynaceae). 
Vachellia caven (espinilho), 80 de Aspidosperma quebrachoblanco (quebracho) e apenas 23 de Prosopis affinis (inhanduvá). ${ }^{42}$

Além da participação expressiva do algarrobo e quebracho-branco, os baixos valores de abundância, dominância e freqüência de Prosopis affinis, são aspectos fitossociológicos distintivos do Algarrobal, em nítido contraste com o observado no Parque de Inhanduvás propriamente dito. No Algarrobal também se encontram, mas com baixa freqüência, as seguintes espécies lenhosas: Parkinsonia aculeata (cina-cina), Acanthosyris spinescens (sombrade-touro), Sapium haematospermum (curupi), Scutia buxifolia (coronilha), Xylosma venosa (sucará), além de dois garupás (Aloysia gratissima, Aloysia chamaedryfolia), e duas taleiras (Celtis ehrenbergiana, Celtis pallid $a^{43}$ ).

A vegetação de menor porte inclui diversas nanofanerófitas (Baccharis microcephala, Baccharis spicata, Mimosa adpressa, Mimosa amphigena), caméfitas (Baccharis coridifolia, B. glutinosa, B. notosergila, Grindelia pulchella, Pluchea oblongifolia, Pterocaulon alopecurioides, $P$. virgatum, $P$. polystachyum), lianas (Dolychandra cynanchoides, Passiflora spp., Gonolobus sellowanus), epífitas (Tillandsia duratii, $T$. lorentziana, $T$. recurvata, $T$. ixioides, Microgramma squamulosa, M. vacciniifolia, Polypodium pleopeltifolium, Lepismium lumbricoides, Lepismium aculeata), e suculentas espinhosas (Cereus hildmannianus, $C$. uruguayanus, Opuntia elata, O. assumptionis, Gymnocalycium schroederianum, Echinopsis rhodotricha, Cleistocactus baumanii).

${ }^{42}$ MARCHIORI, LONGHI \& GALVÃO, 1985b. Op. cit., p. 156.

${ }^{43}$ Embora não citada por MARCHIORETTO (1988) e SOBRAL et al. (2006), esta taleira foi identificada no algarrobal do Parque Estadual do Espinilho por MARCHIORI, LONGHI \& GALVÃO (1985b), constando para a mesma, inclusive, o estudo anatômico de seu lenho (MARCHIORI, J.N.C.; FREITAS, 1993. A. de M. Anatomia da madeira de Celtis pallida Torrey (Ulmaceae). Ciência e Natura, Santa Maria, v. 15, p. 137-147, 1993).
Nas manchas de solo desnudo, ou com vegetação rarefeita, domina uma associação de Briófitas e Gramíneas (Poaceae) de pequeno porte, incluindo: Aristida condyfolia, A. venustula, Bouteloa megapotamica, Gymnopogon sp., Microchloa indica, Pappophorum phllippianum e Tripogon spicatus.

Comparado ao Parque de Inhanduvás propriamente dito, o Algarrobal se destaca pela riqueza de espécies raras, endêmicas ou criticamente ameaçadas no Rio Grande do Sul. Entre outras, ilustram o caso: o próprio algarrobo (Prosopis nigra), o quebracho (Aspidosperma quebrachoblanco), três cravos-do-mato (Tillandsia, duratii, T. ixioides, T. lorentziana), um rabo-de-rato (Lepismium aculeata), três Amarantáceas (Gomphrena perennis, G. pulchella, Pfaffia gnaphalioides), quatro Asteráceas (Acmella psilocarpa, Aspilia pascalioides, Baccharis notosergila, Grindelia scorzonerifolia), quatro Malváceas (Cienfuegosia drummondii, C. sulphurea, C. hassleriana, Sida paradoxa), e três Iridáceas (Calydorea approximata, Catila amabilis, Herbertia crosae). Por si só, esta lista demonstra o valor prioritário que o Algarrobal assume na unidade de conservação, haja vista que a tipologia foi dizimada no Rio Grande do Sul pela expansão da lavoura arrozeira, restando, praticamente, o fragmento conservado no interior do Parque Estadual do Espinilho.

Outro aspecto distinto do Parque de Algarrobos é a ocorrência de espécies florestais em manchas dispersas, geralmente com menos de $10 \mathrm{~m}$ de diâmetro, e associadas a depressões do terreno, resultantes, presumivelmente, do desabamento de antigos ninhos de Atta vollenweideri Forel, saúva com distribuição restrita, no Rio Grande do Sul, a essa tipologia de parque. Com árvores de maior porte ao centro, tais "ilhas" de vegetação silvática contrastam com o parque circundante, incluindo espécies como o aguaí (Chrysophyllum marginatum), o branquilho-leiteiro (Sebastiania brasiliensis), o chal-chal (Allophylus edulis), a pitangueira (Eugenia uniflora), a murta 
(Blepharocalyx salicifolius), o araçá (Myrcianthes cisplatensis), o camboim (Eugenia repanda), o curupi (Sapium longifolium), o veludinho (Guettarda uruguensis), e a embira (Daphnopsis racemosa). Na orla, predominam arvoretas e arbustos espinhosos, tais como: a coronilha (Scutia buxifolia), a taleira (Celtis ehrenbergiana), a unha-de-gato (Senegalia bonaerensis), a cancorosa (Maytenus muelleri), e a japecanga (Smilax campestris).

Para o Algarrobal do Parque Estadual do Espinilho, por fim, há que salientar-se que sua flórula não inclui Trithrinax campestris, apesar da vinculação da espécie a solos alcalinos dos blanqueales, próprios dessa tipologia. Ao contrário do aventado em livro recente sobre Palmeiras do $\mathrm{Brasil}^{44}$, pode-se afirmar que é altamente improvável, em tempo histórico, a ocorrência natural da espécie no Pontal do Quaraí, uma vez que, em território uruguaio, ela não é assinalada para o Departamento de Artigas, vizinho ao Rio Grande do Sul. ${ }^{45}$

\section{CONSIDERAÇÕES FITOGEOGRÁFICAS E TERMINOLÓGICAS}

A ocorrência de duas tipologias de parque, no extremo sudoeste do Rio Grande do Sul, de-

44 “(...) não há registro de sua ocorrência em território brasileiro, contudo, em conversa com antigos moradores da região do Parque do Espinilho no município de Barra do Quaraí - RS, fomos informados da existência, em tempos passados, de uma palmeira com estas características, que os chamavam de "palmeira-de-folha-deespinho"; apesar das intensas buscas nesta região, não conseguimos encontrá-la" (LORENZI, H.; KAHN, F.; NOBLICK, L. R.; FERREIRA, E. Flora brasileira: Arecaceae (Palmeiras). Nova Odessa: Instituto Plantarum, 2010. p. 361). A informação oral de populares, neste caso, parece-nos carente de credibilidade, pela distância que separa o Pontal do Quaraí dos registros assinalados, na literatura, tanto em território uruguaio, como na região de Montiel, na província argentina de Entre Rios.

${ }^{45}$ Frequente em extensas áreas da Argentina, a espécie é "relativamente escasa en el Uruguay", onde ocorre "en montes de algarrobo del borde exterior de los montes fluviales que acompañan al río Uruguay (...) en distintos puntos de los departamentos de Paysandú, Rio Negro y Soriano"(CHEBATAROFF, J. Palmeras del Uruguay. Montevideo: [s.n.], 1974. p. 18). monstra a importância da unidade de conservação criada pelo governo do estado no Pontal do Quaraí. Se a iniciativa oficial não tivesse acontecido, é muito provável que essas singularidades vegetacionais teriam desaparecido na região, cedendo lugar a cultivos agrícolas. Sobre este ponto, cabe ressaltar, ainda, que os fragmentos preservados no Parque Estadual do Espinilho são muito representativos de ambas as tipologias, sobretudo em pontos mais distantes da BR 472.

Outro aspecto que distingue e valoriza o referido Parque, no conjunto das unidades de conservação do Rio Grande do Sul, é seu numeroso contingente de espécies raras, endêmicas e ameaçadas de extinção. Em contraste com sua importância científica no contexto regional, a literatura sobre o Parque Estadual do Espinilho é marcada por confusões e/ou graves equívo$\cos$.

A existência de duas tipologias silváticocampestres na área do Parque Estadual do Espinilho não é detalhe de pouca importância. Só discorda neste ponto quem não quer ver: trata-se de realidade incontestável, uma vez que as mesmas ocupam áreas distintas na natureza, e são facilmente reconhecidas pela composição florística e aspectos ecológicos.

No Parque de Inhanduvás propriamente dito, por exemplo, não se encontram indivíduos de quebracho-branco (Aspidosperma quebrachoblanco) e de algarrobo (Prosopis nigra), entre outras espécies indicativas da tipologia (Parque de Algarrobos).

O não reconhecimento de dois tipos de parque no Pontal do Quaraí, por sua vez, leva a avaliações equivocadas da vegetação, como as cometidas pelo "Inventário Florestal Contínuo do Rio Grande do Sul", que indicou a ocorrência de 63,2 árvores de algarrobo (Prosopis nigra) por hectare na unidade de conservação, seguida, de longe, pelo espinilho (42,0 árvores/ha) e inhanduvá (35,6 árvores/ha). ${ }^{46}$

${ }^{46}$ Ver: RIO GRANDE DO SUL, 2001. Op. cit., p. 268. 
Ninguém ignora, todavia, que o que o inhanduvá é a árvore mais encontradiça no Parque Estadual do Espinilho. O algarrobo, aliás, além de ser uma das árvores mais raras e ameaçadas de extinção no Rio Grande do Sul, nem chegou a ser conhecido por Balduíno Rambo, datando de 1983 o seu primeiro registro na flora nativa do Estado. ${ }^{47}$

Os valores estranhos à realidade, publicados pelo referido inventário, resultam tanto do não reconhecimento dessas tipologias como unidades distintas, como da concentração da amostragem em uma delas - o Parque de Algarrobos -, a qual ocupa, além disso, área menos extensa na unidade de conservação ${ }^{48}$.

Ao contrário do afirmado em diversas publicações, os parques do Pontal do Quaraí também não constituem encraves ou disjunções ${ }^{49}$.

Tratam-se, tão simplesmente, de prolongamento, em território brasileiro, de vegetação dominante na paisagem das províncias argentinas de Corrientes e Entre Rios, à margem direita do Rio Uruguai, e que integram o Distrito do Inhanduvá, no extremo nordeste da província fitogeográfica do Espinhal. ${ }^{50}$ Vinculada a formações sedimentares, a principal barreira a seu avanço, no oeste do Rio Grande do Sul, foi o Planalto da Campanha, com seus solos rasos, gerados a partir de rochas vulcânicas, motivo

${ }^{47}$ MARCHIORI, J.N.C.; LONGHI, S.J.; GALVÃO, L. O gênero Prosopis L. (Leguminosae Mimosoideae), no Rio Grande do Sul. Ciência e Natura, Santa Maria, n. 5, p. 171-177, 1983.

${ }^{48} \mathrm{O}$ tema foi abordado em dois artigos, indicados nas referências bibliográficas: MARCHIORI \& ALVES (2011b), e MARCHIORI \& ALVES (2012a).

49 "Os campos espinhosos sul-riograndenses (...) ocorrem na forma de encraves ou disjunções das formações xerofíticas do Chaco central" (LEITE, P. F., 1994. Op. cit., p. 122). Expressões semelhantes se encontram, por exemplo, em IBGE (2012). Cumpre notar que VELOSO \& GOES-FILHO (1986, p. 561) não cometeram este deslize, uma vez que definiram o Parque Espinilho de Barra do Quaraí como "prolongamento da Estepe Chaquenha da Argentina para o sudoeste do Estado do Rio Grande do Sul".

${ }^{50}$ Distrito del Ñandubay e Província del Espinal (CABRERA \& WILLINK, 1973). pelo qual o Distrito do Inhanduvá e a Província do Espinhal acabaram confinados ao Pontal do Quaraí, e à planície aluvial do Rio Uruguai. Verdadeiros encraves, isto sim, são os parques de inhanduvá recentemente descritos no interior do Planalto da Campanha, em terreno aluvial (Parque do Itapororó ${ }^{51}$, Alegrete) ou em lente de solos arenosos (Parque do Jarau ${ }^{52}$, Quaraí), bem como os encontrados em plena Depressão Periférica, na região do Loreto ${ }^{53}$ (São Vicente do Sul), e na planície sedimentar dos rios Ibicuî́ $^{54}$ (Cacequi) e Santa Maria ${ }^{55}$ (Rosário do Sul).

A respeito do enquadramento dos parques de Barra do Quaraí na "nomenclatura fitogeográfica intertropical", os esquemas produzidos nas últimas décadas demonstram, pela diversidade de interpretações, uma ausência de consenso, na melhor das hipóteses. Em seqüência cronológica, a vegetação em foco foi definida, ora como "Estepe Parque" (Veloso \& GóesFilho, 1982, p. 45; Veloso \& Góes-Filho, 1986, p. 561), ora como "Savana Estépica Parque" (Veloso, Rangel Filho \& Lima, 1991, p. 93; IBGE, 1992, p. 29; IBGE, 2012), ou "Formação Gramíneo-Lenhosa", da "Estepe Estacional Savanícola” (Leite, 1994, p. 121-122).

${ }^{51}$ ALVES, F. da S.; MARCHIORI, J.N.C. O inhanduvá (Prosopis affinis Spreng.) no Rio Grande do Sul. 7 Descrição de um parque natural na várzea do Rio Itapororó, município de Alegrete. Balduinia, Santa Maria, n. 28, p. 1-7, 2011b.

${ }^{52}$ ALVES, F. da S.; MARCHIORI, J.N.C. O inhanduvá (Prosopis affinis Spreng.) no Rio Grande do Sul. 2 Ocorrência natural na região do Jarau, Quaraí. Balduinia, Santa Maria, n. 25, p. 1-9, 2010.

${ }^{53}$ MARCHIORI, J.N.C.; ALVES, F. da S.; PAZ, E.A. O inhanduvá (Prosopis affinis Spreng.) no Rio Grande do Sul. 3 - Parque da Cabanha do Loreto, São Vicente do Sul. Balduinia, Santa Maria, n. 25, p. 22-31, 2010.

${ }^{54}$ MARCHIORI, J.N.C.; ALVES, F. da S. O inhanduvá (Prosopis affinis Spreng.) no Rio Grande do Sul. 6 Descrição de um parque natural na várzea do Rio Ibicuí, município de Cacequi. Balduinia, Santa Maria, n. 27, p. 8-14, 2011a.

${ }^{55}$ ALVES, F. da S.; MARCHIORI, J.N.C. O inhanduvá (Prosopis affinis Spreng.) no Rio Grande do Sul. 5 Ocorrência natural na várzea do Rio Santa Maria, Rosário do Sul. Balduinia, Santa Maria, n. 27, p. 1-7, 2011a. 
Ocorre que os termos "estepe" e "savana" se mostram inapropriados para "descrever os Campos do sul do Brasil", como bem afirmado por Overbeck et al. (2009) e Marchiori (2004), entre outros autores.

Proveniente do russo, a palavra estepe "solo debería ser utilizada para las estepas de gramíneas de la zona temperada", de acordo com Heinrich Walter, autor que conclui sua análise, afirmando que "no existen estepas en los trópi$\cos "{ }^{56}$ Estepes são campos geralmente semiáridos de "clima temperado frio, tais como as pradarias (Prairies) de gramíneas baixas e altas da América do Norte e os campos da Eurásia, desde a Ucrânia até a Mongólia", regiões marcadas por baixas precipitações durante a estação quente, aspecto muito distinto do verificado no sul do Brasil ${ }^{57}$.

O termo Savana, ao contrário, define vegetações tropicais com dois estratos distintos (herbáceo e lenhoso), e precipitação marcadamente sazonal, motivo pelo qual se mostra adequado ao Cerrado do Brasil central, mas não aos campos do Rio Grande do Sul. O mesmo embasamento fitoecológico desautoriza a designação de SavanaEstépica aos parques de Barra do Quaraí.

Cabe notar que parques idênticos aos do Pontal do Quaraí se tornam dominantes na paisagem da Mesopotâmia argentina, à margem direita do Rio Uruguai, e que a Província do Espinhal descreve um grande arco até o litoral atlântico, ao norte da Patagônia, separando o Pampa das províncias fitogeográficas do Chaco e Monte. Com exceção do sul de Corrientes e norte de Entre Rios, que apresentam clima Subtropical sem estação seca ${ }^{58}$, o clima é nitidamente Temperado no restante da Província do Espinhal. O termo Savana Estépica, nestas condições, carece de fundamento.

${ }^{56}$ WALTER, 1977. Op. cit., p. 164-165.

${ }^{57}$ OVERBECK et al., 2009. Op. cit., p. 27.

${ }^{58}$ JOSAMI, J.M.; MUÑOZ, J. de D. Arboles y arbustos indigenas de la Prov. de Entre Rios. Santa Fé: IPNAYS (CONICET - UNL), 1982. p. 47.
Analisado em capítulo anterior, o termo "Parque Espinilho" também se mostra inadequado à vegetação que pretende definir. Resultante de confusão de Lindman e Rambo com a identidade das árvores chaquenhas ${ }^{59}$, o termo alude a Vachellia caven, espécie de ampla distribuição nas áreas campestres do Rio Grande do Sul. Embora nativo nos parques do Pontal do Quaraí, o espinilho não é, certamente, a espécie marcante para a fisionomia e estrutura da vegetação em foco, motivo pelo qual resulta mais conveniente a proposição de Reitz, Klein \& Reis (1983): Parque do Inhanduvá.

\section{REFERÊNCIAS BIBLIOGRÁFICAS}

ALVES, F. da S.; MARCHIORI, J.N.C. O inhanduvá (Prosopis affinis Spreng.) no Rio Grande do Sul. 2 - Ocorrência natural na região do Jarau, Quaraí. Balduinia, Santa Maria, n. 25, p. 1-9, 2010.

ALVES, F. da S.; MARCHIORI, J.N.C. O inhanduvá (Prosopis affinis Spreng.) no Rio Grande do Sul. 5 - Ocorrência natural na várzea do Rio Santa Maria, Rosário do Sul. Balduinia, Santa Maria, n. 27, p. 1-7, 2011a.

ALVES, F. da S.; MARCHIORI, J.N.C. O inhanduvá (Prosopis affinis Spreng.) no Rio Grande do Sul. 7 - Descrição de um parque natural na várzea do Rio Itapororó, Município de Alegrete. Balduinia, Santa Maria, n. 28, p. 1-7, 2011 b.

CABRERA, A.L. Territorios fitogeograficos de la Republica Argentina. Boletín de la Sociedad Argentina de Botánica, v. 4, n. 1-2, p. 21-65, 1951.

CABRERA, A.L.; WILLINK, A. Biogeografia de America Latina. Washington: Secretaría General de la Organización de los Estados Americanos, $1973.120 \mathrm{p}$.

ChebATAROFF, J. Palmeras del Uruguay. Montevideo: [s.n.], 1974. 31 p.

\footnotetext{
${ }^{59}$ Sobre este ponto, recomendamos a análise crítica apresentada em artigo anterior sobre o Pontal do Quaraí (MARCHIORI et al., 2013. Op. cit., p. 1-28).
} 
CUNHA, F.F. da. Apontamentos históricos e informações geraes sobre o município de Quarahy compilados em 1903 pelo intendente Cel. Francisco Flores da Cunha. In: CHEGUHEM, S. S. Quaraí histórico. Quaraí, [s.n.], 1991. v. 2. 229 p. GALVANI, F.R. Vegetação e aspectos ecológicos do Parque Estadual do Espinilho, Barra do Quaraí, RS. Porto Alegre: Universidade Federal do Rio Grande do Sul, 2003. 132 f. Tese de Doutorado (Programa de Pós-Graduação em Botânica).

HIERONYMUS, J. Observaciones sobre la vegetacion de la Província de Tucuman. Boletin de la Academia Nacional de Ciencias Exactas existente en la Universidad de Cordova, Buenos Aires, v. 1, p. 183- 234, 1874.

IBGE - Fundação Instituto Brasileiro de Geografia e Estatística. Manual técnico da vegetação brasileira. Rio de Janeiro: IBGE, 1992. 92 p. (Série Manuais Técnicos em Geociências, n. 1).

IBGE - Instituto Brasileiro de Geografia e Estatística: Manual técnico da vegetação brasileira. Sistema fitogeográfico, inventário das formações florestais e campestres, técnicas de manejo de coleções botânicas, procedimentos para mapeamentos. Rio de Janeiro: IBGE, 2012. (Manuais Técnicos em Geociências, n. 1).

JOSAMI, J.M.; MUÑOZ, J. de D. Arboles y arbustos indigenas de la Prov. de Entre Rios. Santa Fé: IPNAYS (CONICET - UNL), 1982. 407 p.

LEITE, P.F. As diferentes unidades fitoeológicas da região sul do Brasil - Proposta de classificação. 1994. 160 f. Dissertação (Mestrado) - Programa de Pós-Graduação em Engenharia Florestal, Universidade Federal do Paraná - UFPR, Curitiba, 1994.

LINDMAN, C.A.M. A vegetação no Rio Grande do Sul (Brasil Austral). Porto Alegre: Typographia da "Livraria Universal" de Echenique Irmãos \& Cia., 1906. 356 p.

LOMBARDO, A. Noticia de la vegetación de la costa oriental del rio Uruguay en los departamentos de Paysandu, Salto y Artigas. Comunicaciones Botánicas del Museo de Historia Natural de Montevideo, n. 4, p. 1-9, 1943.

LORENZI, H.; KAHN, F.; NOBLICK, L.R.; FERREIRA, E. Flora Brasileira: Arecaceae (Palmeiras). Nova Odessa: Instituto Plantarum, 2010. 368 p.

MARCHIORETTO, M.S. Estudo taxonômico das espécies dos gêneros Celtis e Trema (Ulmaceae) no Rio Grande do Sul. Pesquisas, Série Botânica, São Leopoldo, n. 39, p. 49-80, 1988.

MARCHIORI, J.N.C. Fitogeografia do Rio Grande do Sul: Campos Sulinos. Porto Alegre: EST, 2004. $110 \mathrm{p}$.

MARCHIORI, J.N.C.; ALVES, F. da S. O inhanduvá (Prosopis affinis Spreng.) no Rio Grande do Sul. 6 - Descrição de um parque natural na várzea do Rio Ibicuí, Município de Cacequi. Balduinia, Santa Maria, n. 27, p. 8-14, 2011a.

MARCHIORI, J.N.C.; ALVES, F. da S. A Região do Parque Espinilho e a Bacia Hidrográfica do rio Quaraí, segundo o Inventário Florestal Contínuo do Rio Grande do Sul. Balduinia, Santa Maria, n. 31, p. 3-19, 2011 b.

MARCHIORI, J.N.C.; ALVES, F. da S. A Região do Parque Espinilho e a Bacia Hidrográfica do rio Quaraí, segundo o Inventário Florestal Contínuo do Rio Grande do Sul. Considerações finais. Balduinia, Santa Maria, n. 33, p. 1-8, 2012a.

MARCHIORI, J.N.C.; ALVES, F. da S. Nota sobre a ocorrência natural de Albizia inundata (Mart.) Barneby \& Grimes no Rio Grande do Sul. Balduinia, Santa Maria, n. 33, p. 21-25, 2012 b.

MARCHIORI, J.N.C.; ALVES, F. da S. Nota sobre a distribuição geográfica de Peltophorum dubium (Spreng.) Taub. no Rio Grande do Sul. Balduinia, Santa Maria, n. 33, p. 27-31, 2012c. MARCHIORI, J.N.C.; ALVES, F. da S.; DEBLE, L.P.; DEBLE, A.S. de O. A vegetação no Parque Estadual do Espinilho. 1 - Histórico da ocupação humana e evolução do conhecimento botânico e fitogeográfico sobre o Pontal do Quaraí. Balduinia, Santa Maria, n. 43, p. 1-28, 2013.

MARCHIORI, J.N.C.; ALVES, F. da S.; PAZ, E.A. O inhanduvá (Prosopis affinis Spreng.) no Rio Grande do Sul. 3 - Parque da Cabanha do Loreto, São Vicente do Sul. Balduinia, Santa Maria, n. 25, p. 22-31, 2010.

MARCHIORI, J.N.C.; FREITAS, A. de M. Anatomia da madeira de Celtis pallida Torrey (Ulmaceae). Ciência e Natura, Santa Maria, v. 15, p. 137-147, 1993.

MARCHIORI, J.N.C.; LONGHI, S.J.; GALVÃO, L. O gênero Prosopis L. (Leguminosae Mimosoideae) no Rio Grande do Sul. Ciência e Natura, Santa Maria, n. 5, p. 171-177, 1983.

MARCHIORI, J. N. C.; LONGHI, S. J.; GALVÃO, L. Composição florística e estrutura do parque 
de inhanduvá no Rio Grande do Sul. Rev. Centro de Ciências Rurais, Santa Maria, v. 15, n. 4, p. 319-334, 1985a.

MARCHIORI, J.N.C.; LONGHI, S.J.; GALVÃO, L. Estrutura fitossociológica de uma associação natural de Parque Inhanduvá com quebracho e cina-cina, no Rio Grande do Sul. Ciência e Natura, Santa Maria, n. 7, p. 147-162, 1985b.

MARCHIORI, J.N.C.; SABIN, L. dos S. Identificação botânica de Ruprechtia salicifolia (Cham. \& Schltdl.) C.A. Mey. Balduinia, Santa Maria, n. 20, p. 1-4, 2010.

OVERBECK, G.E., MÜLLER, S.C.; FIDELIS, A.; PFADENHAUER, J.; PILLAR, V. de P.; BLANCO, C.C.; BOLDRINI, I.I.; BOTH, R.; FORNECK, E.D. Os campos sulinos: um bioma negligenciado. In: PILLAR, V. de P.; MÜLLER, S.C.; CASTILHOS, Z.M. de S.; JACQUES, A.V.A. Campos sulinos - conservação e uso sustentável da biodiversidade. Brasília: MMA, 2009. p. 26-41.

RAMBO, A.B. Viagem de Balduíno Rambo ao sudoeste do Rio Grande do Sul no ano de 1941. Balduinia, Santa Maria, n. 36, p. 1329, 2012.

RAMBO, B. A Fisionomia do Rio Grande do Sul. Ensaio de monografia natural. Porto Alegre: Of. Graf. da Imprensa Oficial, 1942. 360 p.

RAMBO, B. A Fisionomia do Rio Grande do Sul. Ensaio de monografia natural. Porto Alegre: Livraria Selbach, 1956. 438 p. (Segunda edição revista).

RAMBO, B. A Fisionomia do Rio Grande do Sul. Ensaio de monografia natural. Porto Alegre: São Leopoldo: Ed. UNISINOS, 2005.472 p. ( $3^{\text {a }}$ edição, $2^{\mathrm{a}}$ reimpressão).

RAMBO, B. Relatório científico das viagens de estudos etnográficos, empreendidas entre 26 de dezembro de 1944 e 14 de março de 1945, pelo
P. Balduíno Rambo S. J., lente de Etnografia e Etnologia da Faculdade de Filosofia da Universidade de Porto Alegre. Revista do Instituto Histórico e Geográfico do Rio Grande do Sul, Porto Alegre, n. 102, p. 234-240, 1946.

REITZ, R.; KLEIN, R.M.; REIS, A. Projeto Madeira do Rio Grande do Sul. Sellowia, Itajaí, n. 3435, p. 1-525, 1983.

RIO GRANDE DO SUL. Governo do Estado. Secretaria Estadual do Meio Ambiente. Inventário Florestal Contínuo do Rio Grande do Sul. Porto Alegre: SEMA/FATEC, 2001. $706 \mathrm{f}$.

SOBRAL, M.; JARENKOW, J.A.; BRACK, P.; IRGANG, B.; LAROCCA, J.; RODRIGUES, R.S. Flora arbórea e arborescente do Rio Grande do Sul, Brasil. Porto Alegre: RiMA : Novo Ambiente, 2006. 350 p.

VELOSO, H.P.; GÓES-FILHO, L. Fitogeografia brasileira: Classificação fisionômica e ecológica da vegetação neotropical. Salvador: Ministério de Minas e Energia, Projeto RADAMBRASIL, 1982. 85 p. (Bol. Téc. Projeto RADAMBRASIL, Série vegetação, 1).

VELOSO, H.P.; GÓES-FILHO, L. 4 - Vegetação. As regiões fitoecológicas, sua natureza e seus recursos econômicos. Estudo Fitogeográfico. In: IBGE - INSTITUTO BRASILEIRO DE GEOGRAFIA E ESTATÍSTICA. Levantamento de Recursos Naturais. v. 33. Folha SH.22 Porto Alegre e parte das Folhas SH.21 Uruguaiana e SI.22 Lagoa Mirim: geologia, geomorfologia, pedologia, vegetação e uso potencial da terra. Rio de Janeiro: IBGE, 1986. 796 p.

VELOSO, H.P.; RANGEL FILHO, A.L.R.; LIMA, J.C.A. Classificação da vegetação brasileira, adaptada a um sistema universal. Rio de Janeiro: IBGE, 1991. 123 p.

WALTER, H. Zonas de vegetación y clima. Barcelona: Omega, 1977. 245 p. 